\title{
Torque teno virus dynamics during the first year of life
}

Elena A. Tyschik', Anastasiya S. Rasskazova², Anna V. Degtyareva', Denis V. Rebrikov ${ }^{1,2^{*}}$ (D) and Gennady T. Sukhikh ${ }^{1}$

\begin{abstract}
Background: Torque teno virus is a small chronically persisting circular negative ssDNA virus reaching near 100\% prevalence. It is reported to be a marker for immune function in immunocompromised patients. The possibility of vertical maternal-fetal transmission remains controversial but incidence rate of TTV DNA in children increased with age. TTV dynamics well studied for allogeneic hematopoietic stem cell transplantation as a predictor of posttransplant complications but there is no viral proliferation kinetics data for other patient groups or healthy individuals. The aim of this study was to determine TTV dynamics during the first year of life of healthy infants.

Methods: Ninety eight clinically healthy breastfeeding infants (1-12 months of age) were analyzed by quantitative PCR for the whole blood TTV load with the test sensitivity of about 1000 viral copies per milliliter of blood (total number of samples including repeatedly tested infants was 109).
\end{abstract}

Results: $67 \%$ of all analyzed samples were TTV-positive demonstrating significant positive correlation between age and TTV load $(r=0.81, p<0.01)$.

Conclusions: This is the first study to suggest that viral load increases during the first year of life reaching a plateau after 6 months with strong proliferation for the first 60 days. Our data well correlates with TTV dynamics in patients following allogeneic hematopoietic stem cell transplantation.

Keywords: Torque teno virus, Transfusion-transmitted virus, TTV, Viral load dynamics, Neonatal period, Infants, TORCH infections

\section{Background}

Torque teno virus (TTV) is a small chronically persisting circular negative ssDNA virus reaching near $100 \%$ prevalence $[1,2]$. TTV is transmitted in all ways including contact and respiratory [3]. It was suggested that presence of TTV can cause several diseases such as acute respiratory diseases [4], liver diseases [5, 6] and cancer [7], but this data did not have any convincing support. It is reported to be a marker for immune function in immunocompromised patients [8].

The routes of mother-to-child transmission of TTV have not been fully elucidated and the possibility of vertical maternal-fetal transplacental transmission remains controversial [9-20]. Also, several authors demonstrated that incidence rate of TTV DNA in children increased

\footnotetext{
* Correspondence: ncagip4@gmail.com

${ }^{1}$ Kulakov National Medical Research Center for Obstetrics, Gynecology and Perinatology, Oparina 4, Moscow 117513, Russia

${ }^{2}$ Pirogov Russian National Research Medical University, Ostrovityanova 1, Moscow 117997, Russia
}

with age $[13,15,19]$, but there is no information about the viral load during the first months of life.

TTV dynamics well studied for allogeneic hematopoietic stem cell transplantation as a predictor of post-transplant complications [21, 22]. But there is no viral proliferation kinetics data for other patient groups or healthy individuals.

The aim of this study was to determine TTV dynamics during the first year of life of healthy breastfeeding infants.

\section{Methods}

\section{Patients and blood samples collection}

This prospective single-center study included 98 clinically healthy breastfeeding infants $(1-12$ months of age, number per month as $9 ; 6 ; 13 ; 8 ; 11 ; 14 ; 6 ; 9 ; 10 ; 6 ; 4 ; 2$ accordingly). 10 infants were tested repeatedly ( 2 or 3 times), so the total number of samples was 109 . The exclusion criteria were as follows: any infectious or genetic 


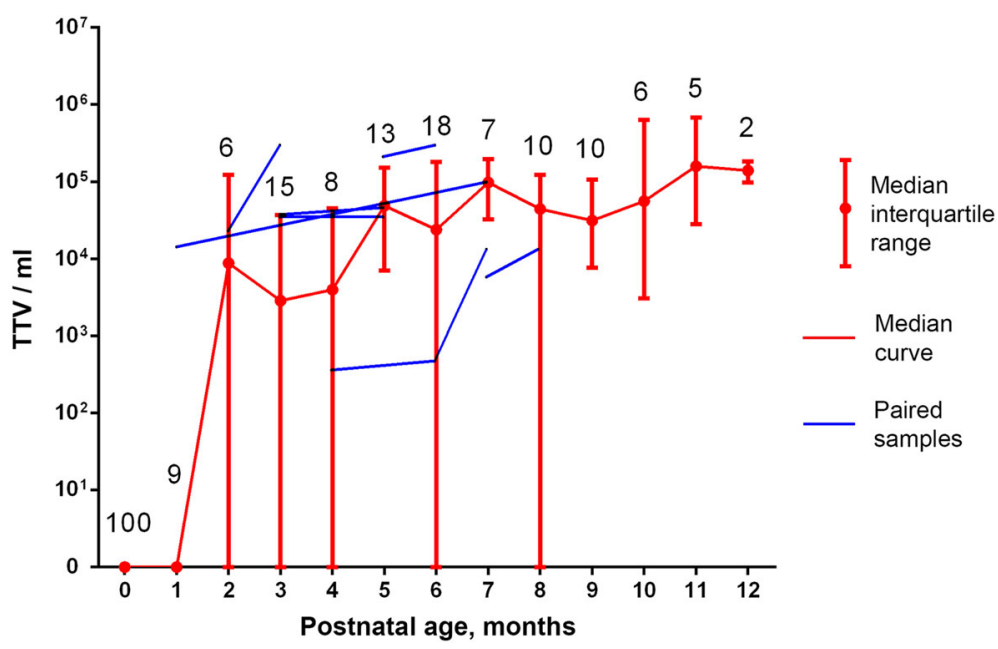

Fig. 1 Torque teno virus dynamics during the first year of life. Data for 0 months from [20]. Numbers correspond to sample size

disease, any immunological deviations, voluntary refusal of research. Two separate aliquots of each capillary blood sample were collected into Microvette 200 K3EDTA (Sarstedt, Germany) between June 2017 and January 2018 at the Kulakov National Medical Research Center for Obstetrics, Gynecology, and Perinatology (Moscow, Russia). Samples were stored at $-20{ }^{\circ} \mathrm{C}$ for $1-7$ days until DNA extraction.

\section{DNA extraction}

DNA was extracted from $50 \mu \mathrm{l}$ aliquots of thawed whole blood using a standard commercial silica-sorbent kit for DNA extraction from body fluids (Probe-GS DNA Extraction Kit, DNA-Technology, Russia). To prevent exogenous contamination, DNA isolation was performed in a separate
DNA extraction room (Zone 1). To prevent cross-contamination of the samples, all procedures were carried out in the UV-equipped PCR-box using sterile disposable tubes and aerosol-resistant tips.

\section{TTV quantification}

qPCR was performed using the DTprime Real-Time PCR Cycler (DNA-Technology, Russia) as described in [1], with the test sensitivity of about 1000 viral copies per milliliter of blood. qPCR of the unique human genome fragment (in a separate PCR tube) was used as DNA extraction control. To prevent PCR contamination by previous reactions or biological samples, the reactions were combined using aerosol-resistant tips in UV-equipped PCR-box in a separate PCR-preparation room (Zone 2).

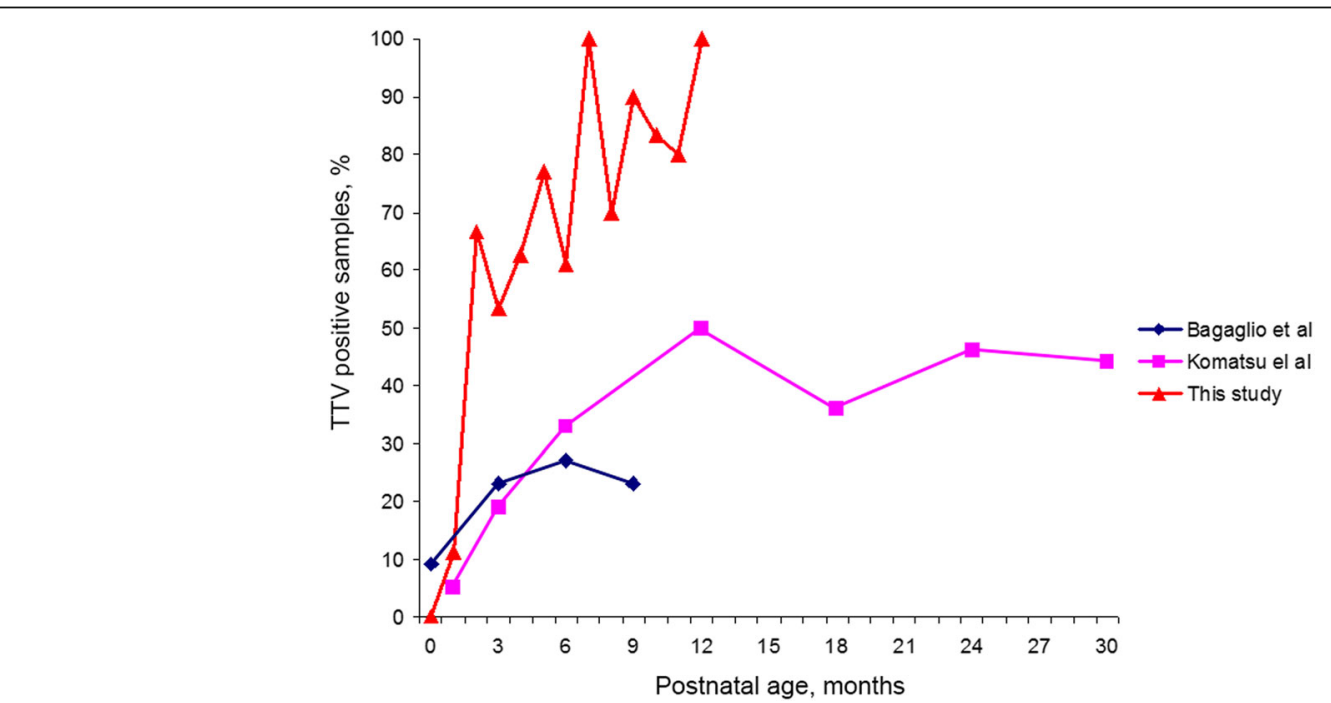

Fig. 2 Percent of TTV DNA positive infants during the first months of life. Data from [15, 19] based on serum analysis 
Also, no electrophoresis of TTV PCR products or other procedures that would require PCR-tube opening were performed in the building. All the negative controls and surface washings were negative.

\section{Data analysis}

qPCR data were analyzed using the DTprime Real-Time PCR Cycler Software v.7.7 (DNA-Technology, Russia). Microsoft Office Excel 2016 (Microsoft Corporation, USA) and GraphPad Prism 6 (GraphPad Software, USA) were used for statistical analysis.

\section{Results}

TTV whole blood viral load was quantified for 98 infants at 1-12 months of age (see. Fig. 1). Because of logistic difficulties only 10 infants were tested repeatedly ( 2 or 3 times) (blue lines at Fig. 1) and only several mother-child pairs were examined for TTV load (data not shown). No breast milk samples were tested.

$67 \%$ of all analyzed samples were TTV-positive (higher than $10^{3}$ copies per $1 \mathrm{~mL}$ of whole blood as a test sensitivity) with median $5 \times 10^{4}$ viral genomes per $1 \mathrm{~mL}$ (range of median values: $0-1,6 \times 10^{5}$ ) demonstrating significant positive correlation between age and TTV load $(r=0.81$, $p<0.01$ ).

For 10 repeatedly tested infants 3 did not show TTV for both tests, 1 was unchanged and other 6 show more TTV in a second analysis (see Fig. 1).

\section{Discussions}

Despite more than twenty years of TTV research, the routes of mother-to-child transmission have not been fully elucidated and the possibility of transplacental TTV transmission remains controversial [9-20]. Some authors demonstrate the absence of TTV in cord blood or baby blood after delivery $[10,13,20]$, but other show $13.8-48.1 \%$ of TTV-DNA positive cord blood samples $[9,11,14,18]$. Such differences can be explained by the low sensitivity of PCR (for studies where the virus did not detected) or by PCR-product contamination (since the cord blood TTV was usually detected by contamination-friendly Nested-PCR technique). In any case, it can be argued that even if the virus passes the transplacental barrier, the cord blood viral concentration is very low and does not depend on the mothers TTV load [20].

The major site of TTV replication is lymphocytes [23-25] and the whole blood TTV load approximately 100 times higher than plasma samples [20]. Consequently, we decided to measure TTV load in the whole blood (instead of plasma or serum) to get more sensitive approach.

Bagaglio et al. and Komatsu et al. demonstrate increasing of the percent of TTV DNA positive infants during the first months of life by serum analysis [15, 19]. Our whole blood results correlates with previous serum data, expectantly showing a greater percentage of positive samples (see Fig. 2).

Breast milk is often positive for TTV (23.3-67.3\%) [13, $14,26]$ and it has been suggested to be one of the major routes of Torque teno virus transmission for babies. So, the newborn TTV progression may be a consequence of the mother's breast milk TTV or immune system changes during the neonatal period.

\section{Conclusions}

This is the first study to suggest that TTV viral load increases during the first months of healthy infants development reaching a plateau after 3-6 months with strong proliferation for the first 60 days. Fast viral load increasing correlates with previous data on TTV DNA prevalence. Also, neonatal TTV dynamics is similar to TTV proliferation in patients following allogeneic hematopoietic stem cell transplantation, demonstrating the possible similarity of intracellular mechanisms of viral progression.

\section{Abbreviations}

PCR: Polymerase chain reaction; qPCR: Quantitative polymerase chain reaction; ssDNA: Single stranded deoxyribonucleic acid; TTV: Torque teno virus; UV: Ultraviolet

\section{Authors' contributions}

EAT and ASR conducted molecular studies and drafted the manuscript, AVD performed the sampling, DVR and GTS designed the study and drafted the manuscript. All authors read and approved the final version of the manuscript.

Ethics approval and consent to participate

The study protocol was reviewed and approved by the Ethics Committee of the Pirogov Russian National Research Medical University (Protocol No.2017/23); the study was conducted in accordance with the Declaration of Helsinki. All participants (children's parents) provided written informed consent.

Competing interests

The authors declare that they have no competing interests.

\section{Publisher's Note}

Springer Nature remains neutral with regard to jurisdictional claims in published maps and institutional affiliations.

Received: 16 March 2018 Accepted: 21 May 2018

Published online: 30 May 2018

\section{References}

1. Vasilyev EV, Trofimov DY, Tonevitsky AG, llinsky W, Korostin DO, Rebrikov DV. Torque Teno virus (TTV) distribution in healthy Russian population. Virol J. 2009; https://doi.org/10.1186/1743-422X-6-134.

2. AbuOdeh R, Al-Mawlawi N, Al-Qahtani AA, Bohol MF, Al-Ahdal MN, Hasan HA, AbuOdeh L, Nasrallah GK. Detection and genotyping of torque teno virus (TTV) in healthy blood donors and patients infected with HBV or HCV in Qatar. J Med Virol. 2015; https://doi.org/10.1002/jmv.24146.

3. Bostan N, Nabgha E Amen, Bokhari H. Current and Future Prospects of Torque Teno Virus. J Vaccines Vaccin. 2013. doi:https://doi.org/10.4172/21577560.S1-004

4. Maggi F, Pifferi M, Tempestini E, Fornai $C$, Lanini $L$, Andreoli $E$, Vatterloni $M$, Presciuttini S, Pietrobelli A, Boner A, Pistello M, Bendinelli M. TT virus load and lymphocyte subpopulations in children with acute respiratory diseases. J Virol. 2003;77:9081-3. 
5. Hsieh S-Y, Wu Y-H, Ho Y-P, Tsao K-C, Yeh C-T, Liaw Y-F. High prevalence of $\Pi T$ virus infection in healthy children and adults and in patients with liver disease in Taiwan. J Clin Microbiol. 1999;37:1829-31.

6. Hafez MM, Shaarawy SM, Hassan AA, Salim RF, El Salam FMA, Ali AE. Prevalence of transfusion transmitted virus (TTV) genotypes among HCC patients in Qalupbia governorate. Virol J. 2007:4:135.

7. McLaughlin-Dubin ME, Munger K. Viruses associated with human cancer. Biochim Biophys Acta. 2008;1782:127-50.

8. Blasek A, Sillo P, Ishii N, Gergely P, Poor G, Preisz K, Hashimoto T, Medvecz $M$, Karpati S. Searching for foreign antigens as possible triggering factors of autoimmunity: torque Teno virus DNA prevalence is elevated in sera of patients with bullous pemphigoid. Exp Dermatol. 2008;17:446-54.

9. Saback FL, Gomes SA, de Paula VS, da Silva RR, Lewis-Ximenez LL, Niel C. Age-specific prevalence and transmission of TT virus. J Med Virol. 1999;59:318.

10. Chen H, Wang YL, Qiu FG, Zhuang LL, Lin YR. Study on TT virus infection of pregnant women and their infant. Chin J Gynecol Obstet. 2000;35:277.

11. Gerner P, Oettinger R, Gerner W, Falbrede J, Wirth S. Mother-to-infant transmission of $T$ virus: prevalence, extent and mechanism of vertical transmission. Pediatr Infect Dis J. 2000;19:1074-7.

12. Kazi A, Miyata H, Kurokawa K, Khan MA, Kamahora T, Katamine S, Hino S. High frequency of postnatal transmission of $T \pi$ virus in infancy. Arch Virol. 2000;145:535-40.

13. Iso K, Suzuki Y, Takayama M. Mother-to-infant transmission of $T \pi$ virus in Japan. Int J Gynaecol Obstet. 2001;75(1):11-9.

14. Matsubara H, Michitaka K, Horiike N, Kihana T, Yano M, Mori T, Onji M. Existence of TT virus DNA and TTV-like mini virus DNA in infant cord blood: mother-to-neonatal transmission. Hepatol Res. 2001;21(3):280-7.

15. Bagaglio S, Sitia G, Prati D, Cella D, Hasson H, Novati R, Lazzarin A, Morsica G. Mother-to-child transmission of TT virus: sequence analysis of non-coding region of TT virus in infected mother-infant pairs. Arch Virol. 2002;147:803-12.

16. Lin $\mathrm{HH}$, Kao JH, Lee PI, Chen DS. Early acquisition of $T$ virus in infants: possible minor role of maternal transmission. J Med Virol. 2002;66:285-90.

17. Ohto H, Ujiie N, Takeuchi C, Sato A, Hayashi A, Ishiko H, Nishizawa T, Okamoto $\mathrm{H}$, vertical transmission of hepatitis viruses collaborative study group. TT virus infection during childhood. Transfusion. 2002:42:892-8.

18. Xin X, Xiaoguang Z, Ninghu Z, Youtong L, Liumei X, Boping Z. Mothertoinfant vertical transmission of transfusion transmitted virus in South China. J Perinat Med. 2004;32:404-6.

19. Komatsu H, Inui A, Sogo T, Kuroda K, Tanaka T, Fujisawa T. TTV infection in children born to mothers infected with TTV but not with HBV, HCV, or HIV. Med Virol. 2004;74:499-506.

20. Tyschik EA, Shcherbakova SM, Ibragimov RR, Rebrikov DV. Transplacental transmission of torque teno virus. Virol J. 2017;14(1):92. https://doi.org/10. 1186/s12985-017-0762-0

21. Wohlfarth P, Leiner M, Schoergenhofer C, Hopfinger G, Goerzer I, Puchhammer-Stoeckl E, Rabitsch W. Torquetenovirus dynamics and immune marker properties in patients following allogeneic hematopoietic stem cell transplantation: a prospective longitudinal study. Biol Blood Marrow Transplant. 2018;24(1):194-9. https://doi.org/10.1016/j.bbmt.2017.09.020

22. Albert, E., Solano, C., Giménez, E., Focosi, D., Pérez, A., Macera, L., ... Navarro, D. (2017). The kinetics of torque teno virus plasma DNA load shortly after engraftment predicts the risk of high-level CMV DNAemia in allogeneic hematopoietic stem cell transplant recipients. Bone Marrow Transplant, (august), 1-8. https://doi.org/10.1038/bmt.2017.235.

23. Maggi F, Fornai C, Zaccaro L, Morrica A, Vatteroni ML, Isola P, et al. TT virus (TTV) loads associated with different peripheral blood cell types and evidence for TV replication in activated mononuclear cells. J Med Virol. 2001;64:190-4

24. Mariscal LF, López-Alcorocho JM, Rodríquez-Iñigo E, Ortiz-Movilla N, de Lucas S, Bartolomé J, et al. TT virus replicates in stimulated but not in nonstimulated peripheral blood mononuclear cells. Virology. 2002;301:121-9.

25. Focosi D, Macera L, Boggi U, Ceccherini Nelli L, Maggi F. Short-term kinetics of torque teno virus viraemia after induction immunosuppression confirm T-lymphocytes as the main replication-competent cells. J Gen Virol. 2015:96:115-7.

26. Goto K, Sugiyama K, Ando T, Mizutani F, Terabe K, Tanaka K, Nishiyama M, Wada Y. Detection rates of $T$ virus DNA in serum of umbilical cord blood breast milk and saliva. Tohoku J Exp Med. 2000;191(4):203-7.

\section{Ready to submit your research? Choose BMC and benefit from:}

- fast, convenient online submission

- thorough peer review by experienced researchers in your field

- rapid publication on acceptance

- support for research data, including large and complex data types

- gold Open Access which fosters wider collaboration and increased citations

- maximum visibility for your research: over $100 \mathrm{M}$ website views per year

At BMC, research is always in progress.

Learn more biomedcentral.com/submissions 